\title{
The monosyllabicization of Old Chinese and the birth of Chinese Writing: A hypothesis on the co-evolution of the Chinese language and its writing system ${ }^{1}$
}

\begin{abstract}
The invention of the Ancient Chinese Writing System (henceforth ACWS) is a significant event in world history. In this paper I put forward a hypothesis on the co-evolution of the Old Chinese language and its writing system (ACWS). I argue that the invention of ACWS bears a strong correlation with the linguistic evolution, more specifically, the monosyllabicization, of Old Chinese. In other words, ACWS might never be invented if monosyllabicization had not occured in Chinese.

The paper is organized in the following way. First, we discuss the reason why a subsyllabic writing system was not invented for Old Chinese (section 2). Next, we discuss the nature of the rebus principle in ACWS (section 3), and its correlation with morphological alternations (section 4). Then I argue that monosyllabicization of Old Chinese is a precondition for the rebus principle, which is crucial for the birth of ACWS (section 5). Lastly, I discuss the implication of the hypothesis for the study of Old Chinese (section 6).
\end{abstract}

Keywords: Old Chinese language, Chinese writing, monosyllabicization, rebus principle, morphological alternations.

\section{Introduction}

The invention of the Ancient Chinese Writing System (henceforth ACWS) is a significant event in world history. The nature and origin of ACWS, however, is still not well understood. In this paper I put forward a hypothesis on the co-evolution of the Old Chinese language and its writing system, ACWS. I argue that the invention of ACWS bears a strong correlation with the linguistic evolution, more specifically, the monosyllabicization of Old Chinese. It is not accidental that Old Chinese became the first language that developed an independent writing system in Southeast Asia.

First, the definition of ACWS and Old Chinese needs some clarification. I use the term ACWS to refer to the earliest systematic writing in Ancient China. In this paper, examples mostly come from oracle bone writing from the later Shang dynasty in the late $2^{\text {nd }}$ millennium BCE, as they are the earliest known form of Chinese writing so far (Keightley 1985). Academics still debate on the question of when ACWS was first invented. Some scholars suggest that

${ }^{1}$ Writing this paper would not have been possible without help from Dr. Ge Liang and Dr. Cheng Shaoxuan, to whom I am most grateful. Certain parts of the paper have been presented at the Workshop on Old Chinese Writing and Chinese Historical Phonology (Shanghai Normal University, Shanghai, China, Oct. 15-16, 2018), and at Old Chinese and Friends: Advances in the Reconstruction of Old Chinese Phonology (Max Planck Institute for the Science of Human History, Jena, Germany, Apr. 26-27, 2018). I thank the participants, especially Dr. Zhang Fuhai, Dr. Zhou Bo, and Dr. Lai Guolong, for their comments. Special thanks go to Dr. Johann-Mattis List and Dr. George Starostin for their detailed review comments. Needless to say, I am responsible for all remaining errors. 
writing systems have been invented as early as the $3^{\text {rd }}$ millennium BCE (Qiu 2013: 34). However, this does not affect the hypothesis put forward here. My argument is that regardless of when the ACWS was invented, certain linguistic innovations must have occurred before this invention.

Old Chinese is defined in this paper as the Chinese language reflected in the earliest known texts, i.e. in the late $2^{\text {nd }}$ millennium BCE. This definition is different from Baxter (1992: 24) where Old Chinese is loosely defined as "Chinese of early and middle Zhou dynasty" (roughly the early and middle $1^{\text {st }}$ millennium BCE), as well as Baxter \& Sagart (2014: 1) where Old Chinese is defined in a broad sense to refer to "varieties of Chinese used before the unification of China under the Qin dynasty in 221 BCE". We do not know yet how much the language of Shang differs from that of Zhou. However, as far as the topic of this paper is concerned, the language of Shang is more closely related to the invention of ACWS than that of Zhou.

\section{Why not a sub-syllabic writing system?}

Unlike modern alphabets, ACWS is a writing system that does not break down syllables into sub-syllabic units. It is natural for a person who lives in our modern, global world to wonder why an alphabetic writing system was never independently invented in China or even Asia in general. The answer to this question is related to the nature of speech production and perception. Many phoneticians and phonologists think of sub-syllabic units like consonants and vowels as universal phonological concepts. However, Ladefoged (2005) disagrees:

Talking involves pulling stored forms of words out of some part of the brain, but words are not stored as sequences of sounds. They are stored as wholes, or at least as whole syllables, in which the consonants and vowels are not separate items. [...] The symbols of the alphabet represent segments of speech, and it is probably from thinking in terms of these symbolized segments that we get the idea that there are separate sounds (Ladefoged 2005: 186-187).

For Ladefoged, sub-syllabic units like consonants and vowels are not universal primitives. Therefore, the history of alphabetic writing should be viewed as a unique invention:

Breaking syllables up into vowels and consonants was an enormous scientific achievement. Speakers of other languages saw what could be done and started using alphabetic characters. But the original notion that syllables could be split into vowels and consonants occurred only once in human history. [...] We also lose out in that our thinking about words and sounds is strongly influenced by writing. We imagine that the letters of the alphabet represent separate sounds instead of being just clever ways of artificially breaking up syllables.

Alphabetic writing has almost certainly been invented only once, whereas there are many independent inventions of systems for writing down syllables (Ladefoged 2005: 189-190).

Phonological knowledge of sub-syllabic units was likely non-existent in native Chinese tradition; it only developed at a later stage through intensive communication with other languages $^{2}$. Therefore, a sub-syllabic writing system was not possible during the time that ACWS was invented. Even for the contemporary Chinese language, O'Seaghdha, Chen \& Chen (2010: 297) argue based on their psycholinguistic studies that "the original or proximate phonological encoding units in Mandarin are syllables whereas in English and related languages they are phonemic segments".

${ }^{2}$ For the development of native Chinese phonological theories, see Halliday (1981). 


\section{The rebus principle in ACWS}

The invention of writing systems was an important milestone in human history. Historically, all ancient writing systems began with the invention of pictograms, semantic symbols for words with concrete meanings. The next stage of development involved figuring out how to represent abstract concepts and functional meaning using only a limited set of symbols, so as to cover the enormous mental lexicon stored in a speaker's brain. One of the most common strategies to solve this problem, developed independently in many ancient writing systems, is the rebus principle. The rebus principle refers to the use of existing symbols purely for their sounds, regardless of their meaning, to represent new words. The application of the rebus principle, which involves the activation of sound at a certain phonological level, is crucial in the invention of all mature writing systems ${ }^{3}$.

In ACWS, the rebus principle was frequently used in the earliest documented oracle bone writing. ${ }^{4}$ A well-known example of rebus principle in Late Shang oracle bone writing is shown in Figure 1.

Figure 1. An example of rebus principle in oracle bone writing

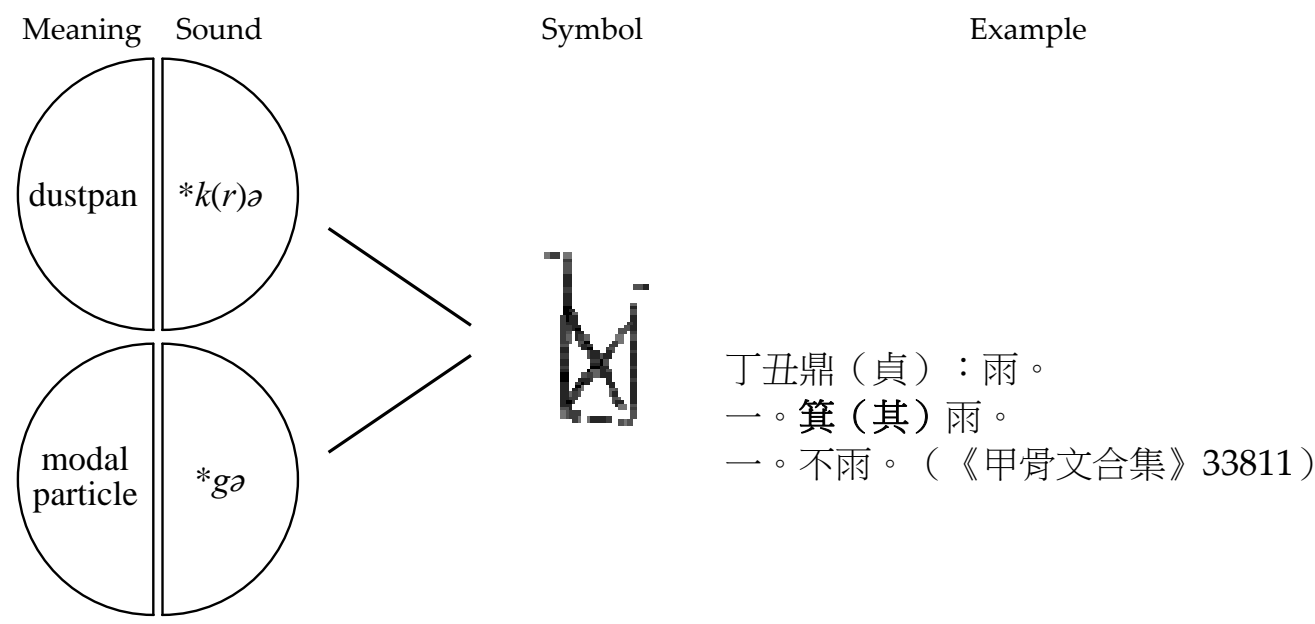

In Figure 1, the symbol invented for the word 'dustpan' 箕 was used for the similarsounding word 'modal particle' 其. This example shows that the rebus principle was often applied to words with abstract meaning. In addition, when applying rebus principle, scribes from different ages or different groups may have used different symbols to write the same word with abstract meaning. For example, words such as 'disaster', 'difficult', 'finish', 'lose', 'faint', 'morning', 'all', 'raise', and 'strange' were written with different symbols by different groups of scribes (Chen 2007).

According to Xia (2014: 72), the rebus usage of characters in oracle bone writing is over $70 \%{ }^{5}$. Although the rebus principle was frequently used, it was not always used whenever

${ }^{3}$ For the development of ancient writing systems, see Robertson (2004) and references therein.

${ }^{4}$ This process is related to the term jiăjiè (literally meaning "borrowing") in the traditional liùshū categorization of Chinese characters developed during the Han period (see Boltz 1994: 143-155 for more details about liùsh $\bar{u}$ ). However, there is a significant difference between the two terms. While jiăjiè refers to a certain type of method to invent new characters, the rebus principle refers to the usage of characters regardless of their origins.

5 The rebus principle is much broader than the jiăjiè method in traditional liùshū categorization. Li (1974) found that 129 out of 1156 (about 11\%) characters were invented by the jiăjiè method. 
possible. On the contrary, in numerous cases when rebus usage was possible, it was not applied. Figure 2 shows one such example.

Figure 2. An example of the limitation of rebus principle in oracle bone writing

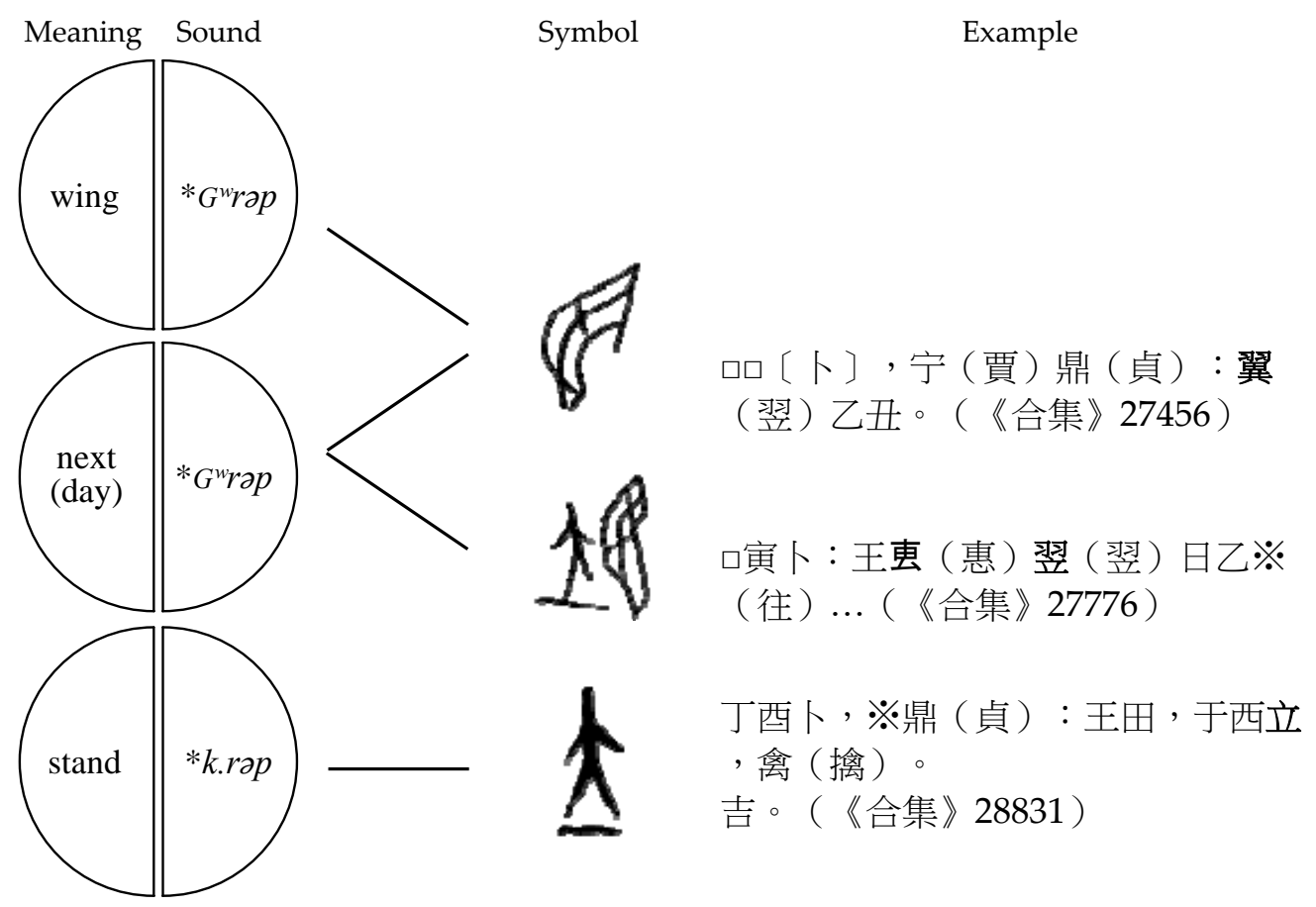

In Figure 2, the word 'next (day)' can be represented by two kinds of graphs, one with a pictograph of 'wing', and the other with a complex character composed of a pictograph of 'wing' plus an additional pictograph of 'stand'. However, the symbol for 'stand' is used only for 'stand' and never appears as a rebus for 'next (day)'. The reason why there is no rebus between 'tomorrow' and 'stand' is not because they are not phonetically close enough; otherwise 'stand' would not be added as a symbol indicating the sound in the complex character. Instead, it is because the rebus usage of 'wing' for 'next (day)' is well established, and 'stand' is frequently used for its original meaning 'stand'; thus the two symbols were kept apart to signal different semantic meanings.

The limited application shown here and other numerous cases indicate that the rebus principle is only a backup option when the semantic meaning of a word is difficult to convey directly by pictograph. Unlike a syllabic writing system where most symbols have lost their semantic meanings and are only used to represent sounds, most concrete words are represented by pictographs in ACWS even when rebus usage of other symbols is possible. Therefore, the distinction of meanings is much more important than economy of symbols in ACWS. In fact, this is one of the main reasons why most scholars consider ACWS as a logographic writing system rather than a syllabic writing system.

\section{Rebus and Old Chinese morphological alternations}

In ACWS, rebus principle was applied to both homophonic and near-homophonic monosyllabic words. For near-homophonic pairs, certain phonological contrasts did not block the usage of rebus principle, while others frequently did. Three phonological contrasts in Old 
Chinese which almost never blocked rebus usage are qīngzhuó ${ }^{6}$, sìshēng ${ }^{7}$, and děng ${ }^{8}$ respectively. Table 1 contains some examples.

Table 1. Three examples of rebus usage across certain phonological contrasts

\begin{tabular}{|c|c|c|c|c|c|}
\hline & \multirow[t]{2}{*}{ Gloss } & \multicolumn{3}{|c|}{$\begin{array}{l}\text { Middle Chinese } \\
\text { phonological contrasts }{ }^{9}\end{array}$} & \multirow[t]{2}{*}{ Example } \\
\hline & & qīngzhuó & sìshēng & děng & \\
\hline 箕 & dustpan & qúanqīng & & & \multirow{2}{*}{$\begin{array}{l}\text { 丁丑鼎（貞）：雨。一。箕 (其) 雨。 } \\
\text { 一。不雨。（《合集》33811） }\end{array}$} \\
\hline 其 & modal particle & qúanzhuó & & & \\
\hline 皿 & utensil & cìzhuó & shăng & & \multirow{2}{*}{ 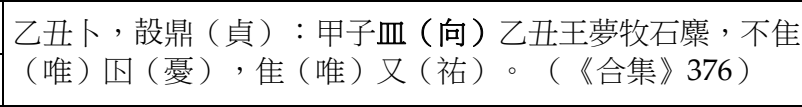 } \\
\hline 向 & to face & qúanqīng & $q \grave{u}$ & & \\
\hline 擐 & put on clothing & cìhuó & qù & $2^{\text {nd }}$ & \multirow{2}{*}{ 口其田于口，其擐（遠），〔湄〕日亡※（災）。 } \\
\hline 遠 & far & qúanzhuó & shăng & $3^{\text {rd }}$ & \\
\hline
\end{tabular}

In Table 1, the first rebus usage ('dustpan' for 'modal particle', see Figure 1 for details) involves qingzhuó contrast, the second rebus usage ('utensil' for 'to face', see Qiu 1993) involves both qingzhuó contrast and sishēng contrast, and the last rebus usage ('put on clothes' for 'far', see Qiu 1985) involves all three contrasts. In these cases and many others, rebus is not blocked by these three phonological contrasts. Notably, all three also appear in morphological alternations in Old Chinese ${ }^{10}$. Table 2 gives some examples.

Table 2. Examples of morphological alternations in Old Chinese

\begin{tabular}{c|c|c|c|c}
\hline \multirow{2}{*}{} & \multirow{2}{*}{ Gloss } & \multicolumn{2}{|c}{ Middle Chinese phonological contrasts } \\
\cline { 3 - 5 } & qüngzhuó & sìshēng & děng \\
\hline 敗 & defeat (v.t.) & qúanqīng \\
敗 & suffer defeat & qunzhuó & & \\
\hline 受 & receive & & shăng & \\
授 & give & & qù & $3^{\text {rd }}$ \\
\hline 封 & enfeoff & & & $2^{\text {nd }}$ \\
邦 & country & & rù & $3^{\text {rd }}$ \\
\hline 入 & enter & & qù & $1^{\text {st }}$ \\
内 & inside & & rù & \\
\hline 學 & learn & qúanzhuó & qù & \\
教 & teach & qúanqīng & & \\
\hline
\end{tabular}

${ }^{6}$ Qingzhuó (清浊) is a traditional term related to Middle Chinese consonantal initials. There are four subsets: qúanqīng (全清), cìqing (次清), qúanzhuó (全浊), and cizhuó (次浊).

7 Sisheng (四聲) is a traditional term related to Middle Chinese tones. There are four subsets: pinng (平), shăng (上), qù (去), rù (人).

${ }^{8}$ Děng (等) is a traditional term related to Middle Chinese Medial and/or vowel qualities. There are four subsets: $1^{\text {st }}$ (一等), $2^{\text {nd }}$ (二等), $3^{\text {rd }}$ (三等), and $4^{\text {th }}$ (四等).

9 These are traditional Chinese phonological terms invented for Middle Chinese. I intentionally use these abstract terms in order to avoid the controversy over their phonetic details in Old Chinese. See the previous footnotes for details.

${ }^{10}$ Old Chinese shows no evidence of reconstructing inflectional morphology; only derivational morphology can be reconstructed (LaPolla 2003). 
In Table 2, there are five pairs of morphological alternations. The first three pairs differ in qingzhuó, sìshēng, and děng respectively. The fourth pair differs in both sishēng and děng, while the last pair differs in both qìngzhuó and sìshèng. The qingzhuó alternation is one of the most frequent morphological alternations in Old Chinese ${ }^{11}$. The sishēng alternation is also an active morphological device that has received much attention ${ }^{12}$. The děng alternation has received relatively less attention ${ }^{13}$.

Why are the phonological contrasts omitted in the writing system and those used as morphological devices the same - is this just a coincidence?

According to classic phonological theories (Dresher, Piggott, \& Rice 1994), a phonological relationship is either contrastive or non-contrastive. In other words, contrastive phonological features are contrastive to the same extent. However, Hall (2009) proposes a new understanding of phonological relationships in terms of a continuum with contrastive and noncontrastive at either end.

Figure 3. A continuous set of phonological relationships (Hall 2009:16)

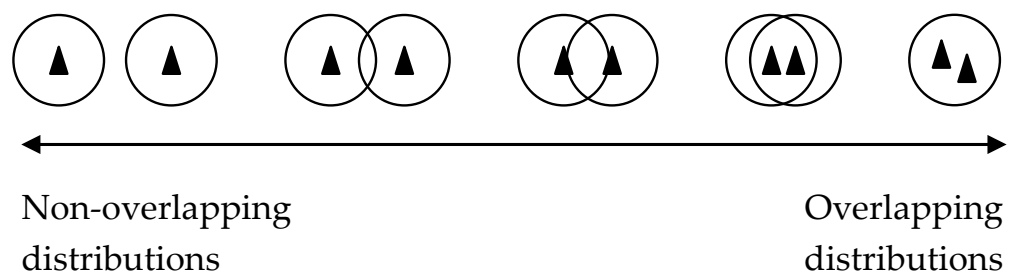

According to the proposal illustrated in Figure 3, phonological relationships are gradient rather than categorical. Besides the contrastive and non-contrastive relationships, there could be something in between. Multiple factors could lead to an intermediate status of this phonological relationship, one of them being morphology. When a set of phonological features is used to differentiate words, it is contrastive. However, its differentiating function could be contracted to some extent when the same set of features is applied to a word pair with the same morphological root. As a result, those phonological features used in morphological alternations have an intermediate status between contrastive and non-contrastive.

Therefore, when the rebus principle extends its application from homophones to nearhomophones, those features used in morphological alternations are the most suitable candidates because they are less contrastive than other phonological contrasts which are not used in morphological alternations.

\section{The monosyllabicization of Old Chinese as a precondition for rebus}

In this chapter, we will discuss the precondition for rebus in ACWS, focusing on the case of qingzhuó, one of the most popular morphological devices and also a phonological contrast that does not block rebus. Table 3 lists two pairs of words which differ only in terms of qīngzhuó categories.

\footnotetext{
${ }^{11}$ See Sagart (2003), Phua (2004), Handel (2012), Jacques (2018), among others.

12 This alternation is also known as the "qù tone alternation" since the derived forms are almost always Middle Chinese qù tone. See Downer (1959), Mei (1980), Jacques (2016), among others.

${ }^{13}$ See Yu (1999) for the 3rd-deng and non-3rd-deng alternation, and Sagart (1999) for the reconstructed - $r$ - infix for the 2nd-deng derivation from non-2nd-deng.
} 
Table 3. Reconstruction of the qīngzhuó contrast in Old Chinese

\begin{tabular}{|c|c|c|c|c|}
\hline & 敗 & 敗 & 伯 & 白 \\
\hline & defeat(v.t.) & suffer defeat & eldest & white \\
\hline Middle Chinese & paejH & baejH & paek & baek \\
\hline Old Chinese (Zhengzhang 2003) & praads & braads & praag & braag \\
\hline Old Chinese (Baxter \& Sagart 2014) & $\mathrm{p}^{\S} \mathrm{a}[\mathrm{t}]-\mathrm{s}$ & $N-p^{\varepsilon} a[t]-s$ & prak & brak $^{\text {frak }}$ \\
\hline
\end{tabular}

As shown in Table 3, while qingzhuó categories are reconstructed as voicing contrasts in Middle Chinese, scholars have different opinions on their reconstructed forms in Old Chinese. Some scholars, represented by Zhengzhang (2003), project the voicing contrast in Middle Chinese directly back to Old Chinese. Other scholars, represented by Baxter \& Sagart (2014), propose two origins for the Middle Chinese voicing contrast (henceforth called two-origins proposal). For those pairs involved in morphological alternations, they reconstruct a prefix ${ }^{*} \mathrm{~N}$ - as the source of voiced consonants, while for those pairs that were not involve in such alternations, they project the voicing contrast back to Old Chinese ${ }^{14}$.

In terms of writing, the rebus method could be applied to both types of pairs regardless of whether they are morphologically related. For example, the first two words meaning 'defeat (v.t.)' and 'suffer defeat' in Table 3 are represented by the same character 敗, while the second two, meaning 'eldest' and 'white', are both represented by the same character 白 in ACWS. If the proposal about phonological relationships outlined in Chapter 4 is on the right track, then, when reconstructing Old Chinese, we must maintain a similar phonological relationship as reflected in Middle Chinese regardless of their morphological relations. Therefore, our hypothesis favors the first approach represented by Zhengzhang (2003).

However, this does not mean that the two-origins proposal by Baxter \& Sagart (2014) is wrong, as it is supported by comparative evidence ${ }^{15}$. In fact, both proposals in Table 3 could be right, if we regard them as reflecting different evolutionary stages of the Chinese language: the two-origins proposal could be true for Proto-Chinese, when the ancestor of the Chinese languages first split from other Tibeto-Burman languages, while the two origins could have already merged into one in Old Chinese, when the writing system was invented. In other words, although the ultimate origin of the qingzhuó alternation was prefixation, it had already become a stem alternation at the stage of Old Chinese.

This brings us to the problem of reconstructing the word-template in Old Chinese. Scholars have different views on this issue: many Chinese scholars reconstruct a monosyllabic word-template for Old Chinese (see Ding 2002 for a review), while Baxter \& Sagart (2014) reconstruct the word-template shown in Figure 4.

Baxter \& Sagart (2014) regard the word template in Figure 4 as iambic-disyllable ${ }^{16}$. Following Pittayaporn's (2015) definition of sesquisyllable, ${ }^{17}$ we classify it as sesquisyllable rather

${ }_{14}$ An alternative hypothesis which reconstructs an *s- prefix as the source of voiceless consonants has also been proposed (see Handel 2003 for a review). Nevertheless, the details of reconstruction are not relevant here. The alternative hypothesis may be viewed as a variant of the "two-origins proposal", since its proponents reconstruct different phonological contrasts for pairs that were involved in morphological alternation and for those that were not.

${ }^{15}$ See Sagart (2003) for details. Also, see Phua (2004) for typological concerns on reconstructing prefixation rather than stem alternation.

${ }^{16}$ See Brunelle \& Pittayaporn (2012) for further details of this term.

17 Pittayaporn (2015) defines "sesquisyllable" as "a prosodic word consisting of a full stressed syllable preceded by a consonant or a sequence of consonants. The consonant or consonant sequence must not contain a phonemically contrastive vowel." 
than iambic-disyllable. From a diachronic perspective of monosyllabicization, a word-template evolution widely attested in Asian languages (Michaud 2012), sesquisyllable is a common intermediate stage from iambic-disyllable to monosyllable, as discussed in detail in Brunelle \& Pittayaporn (2012), shown in Figure 5.

Figure 4. Hypothetical Old Chinese word-template (Baxter \& Sagart 2014: 53)

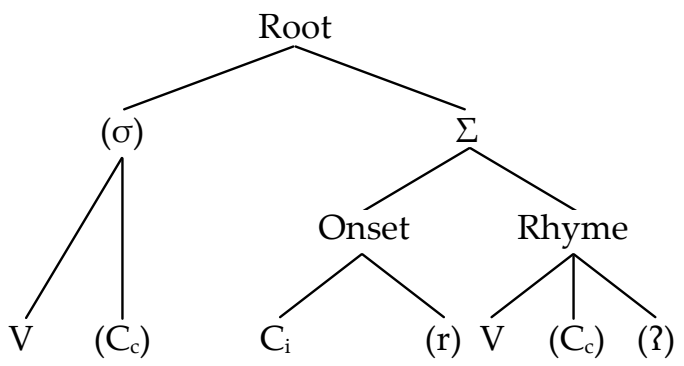

Figure 5. Word-type shifts (uneven iamb>sesquisyllable>monosyllabic iamb) ${ }^{18}$

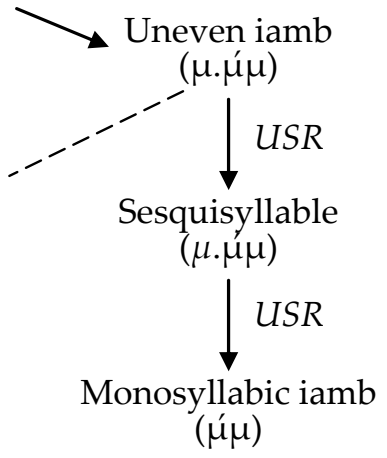

If we accept that Chinese also went through the monosyllabicization process, ${ }^{19}$ then, the question of reconstructing the word-template in Old Chinese is not a matter of right and wrong. Rather, the question should be reframed as: At which stage in the evolution process was Old Chinese?

We have argued that the application of the rebus method in ACWS could be better explained in terms of a language system where prefixation had already changed to stem alternation. This is very likely to be a byproduct of the monosyllabicization process outline in Figure 5 , where the minor syllables in the iambic-disyllable template became pre-initials in the sesquisyllabic template, or consonant clusters in the monosyllabic template. As a result of these word-type shifts, morphological alternations originally derived from prefixation gradually became less and less productive, and finally remained only in fossilized forms ${ }^{20}$.

This hypothesis is also supported by a recent proposal on the role that language contact must have played in the formation of the Chinese language. It has long been recognized that

${ }^{18}$ This figure is a part of the original figure in Brunelle \& Pittayaporn (2012: 424), where they emphasize the important role of rhythmic effects on word-type shifts.

${ }_{19}$ Salmons \& Zhuang (2018: 556) proposed a hypothetical evolution cycle from Proto-Chinese to Modern Chinese. They regard the reconstructed iambic-disyllable template as the initial stage of Proto-Chinese, and argue that the Chinese language changed to a monosyllabic template through an intermediate stage of $C(C) V(C)$, before returning to the disyllabic template again in Modern Chinese.

${ }^{20}$ A similar case could be found in the fossilization of the suffix * $n$ in modern Wu dialects, see Fang (1993) and references therein. 
the division between Northern and Southern Chinese dialects and the typological shift from Old Chinese to modern Chinese is largely due to language contact between Chinese and various neighboring language families (Hashimoto 1978, Mei 1997). Recent studies suggest that the origin of the Chinese language may also be a result of language contact. Delancey (2013) argues that "the language of Shang was a highly-creolized lingua franca based on languages of the Southeast Asian type". Although the exact nature and chronology of the language contacts that shaped Old Chinese require further study, the scenario is very much compatible with our hypothesis that the linguistic innovation of Old Chinese provided the basis for the wide application of rebus (the rebus principle), which ultimately gave rise to the birth of the Ancient Chinese Writing System.

\section{Implication and future direction}

In this paper I put forward a hypothesis on the co-evolution of the Old Chinese language and its writing system, ACWS. I have argued that the invention of ACWS bears a strong correlation with the linguistic evolution, more specifically monosyllabicization, of Old Chinese. In other words, ACWS may have never been invented if Chinese had not gone through monosyllabicization.

If the hypothesis we have proposed is convincing, it will have a significant consequence for the study of Old Chinese. To understand better the evolution of Chinese languages, it seems necessary to distinguish two different stages. One is Proto-Chinese or Pre-Old-Chinese, which represents a stage that predates the invention of Chinese writing. The other is Old Chinese, which represents a stage when the writing system has already been invented. The evidence for reconstructing Proto-Chinese will mainly come from comparison with other SinoTibetan languages, while the evidence for reconstructing Old Chinese will mainly be based on excavated texts, including writing practice, rhyming patterns, and the formation of word families.

Regarding the direction of possible future research, we would like to explore the similarities and dissimilarities between independently invented writing systems and seek for potential parallels that might show a similar nature to the origin of the Ancient Chinese Writing System.

\section{References}

Baxter, William H. 1992. A handbook of Old Chinese phonology. Berlin: Walter de Gruyter.

Baxter, William H., Laurent Sagart. 2014. Old Chinese: A new reconstruction. Oxford: Oxford University Press.

Boltz, William G. 1994. The origin and early development of the Chinese writing system. Indiana: Eisenbrauns.

Brunelle, Marc, Pittayawat Pittayaporn. 2012. Phonologically-constrained change: The role of the foot in monosyllabization and rhythmic shifts in Mainland Southeast Asia. Diachronica 29(4): 411-433.

Chen, Jian (陳劍). 2007. Yinxu buci de fenqi fenlei dui jiagu wenzi kaoshi de zhongyaoxing (殷噓卜辭的分期分類對甲骨文字考釋的重要性). Jiagu jinwen kaoshi lunji (甲骨金文考釋論集): 317-453. Beijing: Xianzhuang shuju (綫裝書局).

DeLancey, Scott. 2013. The origins of Sinitic. In: Zhuo Jing-Schmidt (ed.). Increased Empiricism: New Advances in Chinese Linguistics: 73-99. Amsterdam: John Benjamins Publishing.

Ding, Bangxin (丁邦新). 2002. Shangguhanyu de gouci wenti shuping (上古汉语的构词问题述评). Yuyanxue luncong (语言学论丛) 26: 1-11.

Downer, Gordon B. 1959. Derivation by tone-change in Classical Chinese. Bulletin of the School of Oriental and African Studies 22(2): 258-290.

Dresher, B. Elan, Glyne Piggott, Keren Rice. 1994. Contrast in phonology: Overview. Toronto Working Papers in Linguistics 13(1): iii-xvii. 
Fang, Songxi (方松喜). 1993. Zhejiang wufangyan li de erwei (浙江吴方言里的儿尾). Zhongguo yuwen (中国语文) 2: 134-139.

Guo, Moruo (郭沫若), Hu Houxuan (胡厚宣) (eds.). 1982. Jiaguwen heji (甲骨文合集). Beijing: Zhonghua shuju (中华书局).

Hall, Kathleen C. 2009. A probabilistic model of phonological relationships from contrast to allophony. Doctoral dissertation. The Ohio State University.

Halliday, Michael A. 1981. The origin and early development of Chinese phonological theory. In: R. E. Asher, Eugenie J. A. Henderson (eds.). Towards a history of Phonetics: 123-140. Edinburgh University Press.

Handel, Zev. 2012. Valence-changing prefixes and voicing alternation in Old Chinese and Proto-Sino-Tibetan: Reconstructing * $\mathrm{s}$ - and ${ }^{*} \mathrm{~N}$-prefixes. Language and Linguistics 13: 61-82.

Hashimoto, Mantaro J. 1978. Language Typology and Geography. Tokyo: Kobundo.

Jacques, Guillaume. 2016. How many *-s suffixes in Old Chinese? Bulletin of Chinese linguistics 9(2): 205-217.

Jacques, Guillaume. 2018. Fossil normalization prefixes in Tibetan and Chinese. Paper presented at the $2^{\text {nd }} \mathrm{Li}$ Fang-Kuei Society Young Scholars Symposium, Institute of Linguistics, Academia Sinica, Taiwan, 12-15, Jul. 2018.

Keightley, David N. 1985. Sources of Shang history: The oracle-bone inscriptions of Bronze Age China. Oakland: University of California Press.

Ladefoged, Peter. 2005. Vowels and consonants: An Introduction to the Sounds of Languages (second edition). Oxford: Blackwell.

LaPolla, Randy J. 2003. Overview of Sino-Tibetan morphosyntax. In: Randy J. LaPolla, Graham Thurgood (eds.). The Sino-Tibetan Languages: 22-42. London / New York: Routledge.

Li, Xiaoding (李孝定). 1974. Jiaguwen de liushufenxi (甲骨文的六書分析). Bulletin of the Institute of History and Philology (中央研究院歷史語言研究所集刊) 45(2): 374-380.

List, Johann-Mattis, Anselm Terhalle, Daniel Schulzek. 2016. Traces of embodiment in Chinese character formation. A frame approach to the interaction of writing, speaking, and meaning. In: Ströbel, L. (ed.). Sensorymotor concepts. At the crossroad between language \& cognition: 45-62. Düsseldorf University Press.

Mei, Zulin (梅祖麟). 1980. Sishengbieyi zhong de shijian cengci (四声别义中的时间层次). Zhongguo yuwen (中国语文) 6: $427-443$.

Mei, Zulin (梅祖麟). 1997. Hanyu qige leixingtezheng de laiyuan (汉语七个类型特征的来源). Zhongguo jingnei yuyan ji yuyanxue (中国境内语言暨语言学) 4: 81-103.

Michaud, Alexis. 2012. Monosyllabicization: Patterns of evolution in Asian languages. In: Thomas Stolz, Nicole Nau, Cornelia Stroh (eds.). Monosyllables: from phonology to typology: 115-130. Berlin: De Gruyter Mouton.

O'Seaghdha, Padraig G., Jenn-Yeu Chen, Train-Min Chen. 2010. Proximate units in word production: Phonological encoding begins with syllables in Mandarin Chinese but with segments in English. Cognition 115(2): 282-302.

Pittayawat Pittayaporn. 2015. Typologizing sesquisyllabicity. In: N. J. Enfield, Bernard Comrie (eds.). Languages of Mainland Southeast Asia: The state of the art: 500-528. Berlin: De Gruyter Mouton.

Phua, Chiew Pheng (潘秋平). 2004. Shangguhanyu zhong de qingzhuobieyi jiqi xiangguan de wenti (上古漢語 中的清濁別義及其相關問題). In: Dingbangxin jiaoshou rongxiu jinian lunwenji (丁邦新教授榮休紀念論文集): 1-63. Hong Kong: Center for Chinese Linguistics, Hong Kong University of Science and Technology.

Qiu, Xigui (装锡圭). 1985. Shi yinxujiaguwen li de yuan er ji youguanzhuzi (释殷墟甲骨文里的远迩及有关诸字). Beijing: Zhonghua shuju (中华书局).

Qiu, Xigui (装锡圭). 1993. Shi yinxubuci zhong de ming dengzi (释殷虚卜辞中的 皿等字). In: Di erjie guoji zhongguo guwenzixue yantaohui lunwenji (第二届国际中国古文字学研讨会论文集). Hong Kong: Xianggang zhongwendaxue zhongguoyuyanjiwenxuexi (香港中文大学中国语言及文学系).

Qiu, Xigui (装锡圭). 2013. Wenzixue gaiyao (文字学概要). Beijing: Shangwu yinshuguan (商务印书馆).

Robertson, John S. 2004. The possibility and actuality of writing. In: Stephen D. Houston (ed.). The first writing: Script invention as history and process: $16-38$. Cambridge University Press.

Rogers, Henry. 2004. Writing systems: A linguistic approach. Blackwell Textbooks In Linguistics.

Sagart, Laurent. 1999. The roots of old Chinese. Amsterdam: John Benjamins Publishing.

Sagart, Laurent. 2003. Sources of Middle Chinese manner types: Old Chinese prenasalized initials in Hmong-Mien and Sino-Tibetan perspective. Language and Linguistics 4(4): 757-768.

Salmons, Joseph, Zhuang Huibin. 2018. The diachrony of East Asian prosodic templates. Linguistics 56(3): 549-580.

Xia, Dazhao (夏大兆). 2014. Jiaguwen ziyong yanjiu (甲骨文字用研究 ). Doctoral dissertation. Anhui daxue (安徽大学). 
Yu, Min (俞敏). 1999. Guhanyu paisheng xinci de moshi (古汉语派生新词的模式). Yumin yuyanxue lunwenji (俞敏语言学论文集). Beijing: Shangwu yinshuguan (商务印书馆).

Zhengzhang, Shangfang (郑张尚芳). 2003. Shanggu yinxi (上古音系). Shanghai: Shanghai Educational Publishing House (上海教育出版社).

Шәнь Жуйцин. Моносиллабизация в древнекитайском языке и генезис китайской иероглифики: гипотеза о совместной эволюции китайского языка и китайской письменной системы

В статье выдвигается гипотеза относительно совместной эволюции древнекитайского языка и сложившейся на его основе системы письменности. Утверждается, что изобретениее китайской письменности тесно коррелирует с лингвистической эволюцией китайского языка, в особенности его моносиллабизацией, и что без перехода китайского к односложной структуре слова изобретение такого рода письменности было бы невозможно.

Работа начинается с обсуждения возможных причин того, что для древнекитайского языка не была изобретена алфавитная система письма. Вслед за этим анализируются особенности ребусного принципа в устройстве древнекитайской письменности и его связь с морфологическими чередованиями; приводятся аргументы в пользу того, что обязательным условием для появления ребусного принципа (и вместе с ним собственно древнекитайского письма) является моносиллабизация. В последней части работы обсуждается значимость данной гипотезы в общем контексте изучения древнекитайского языка.

Ключевые слова: древнекитайский язык, китайская письменность, моносиллабизация, ребусный принцип, морфологические чередования. 